\title{
Patients' psychosocial well-being and self-reported satisfaction following single implant therapy in Lagos, Nigeria
}

\author{
Kolawole Obagbemiro ${ }^{1, *}$, Adeoye John Ademola ${ }^{2}$, Ajayi Yetunde ${ }^{3}$, Akeredolu Patricia Adetokunbo ${ }^{4}$, \\ Arotiba Godwin Toyin ${ }^{5}$
}

\begin{abstract}
${ }^{1}$ Prosthetic Dentistry Unit, Federal Medical Centre (FMC), Abeokuta, Ogun State, ${ }^{2}$ Dental and Maxillofacial Surgery Department, State House Medical Centre (SHMC), Aso Rock, Abuja, ${ }^{3,4}$ Dept. of Restorative Dentistry, ${ }^{5}$ Dept. of Oral and Maxillofacial Surgery, Lagos University Teaching Hospital (LUTH) and College of Medicine, University of Lagos (CMUL), Nigeria
\end{abstract}

*Corresponding Author: Kolawole Obagbemiro

Email: kollydental@yahoo.co.uk

\begin{abstract}
Introduction: Missing teeth which is one of the main reasons for dental visitation affect individuals in various ways. While some individuals are unaffected by having a missing tooth, others have reduced self-confidence, become anxious and some ultimately become depressed. This study aims to determine the satisfaction of patients as well as their psychosocial wellbeing following single implant therapy.

Materials and Methods: This is a longitudinal, interventional clinical study. Subjects were recruited using non-probability sampling methods. Data was collected using self-administered questionnaires distributed to patients at two phases of treatment. Baseline data was collected at the time of treatment planning and at six months following implant placement. Data analysis was done using Statistical package for the social sciences (SPSS) version 20.

Results: A total of 42 subjects were recruited into this study comprising equal numbers of males and females. A comparison of the baseline data and data collected at six months revealed that most subjects $(n=41,97.6 \%)$ had an overall positive reaction to the treatment. Also, an improvement in self-confidence was observed in $78.6 \%(\mathrm{n}=33)$ of subjects. Regarding patients' satisfaction following treatment, $76.2 \%(n=32)$ of the subjects were very satisfied with the outcome of the implants. All respondents $(n=42,100 \%)$ were however willing to recommend implant therapy for other individuals seeking to replace their missing tooth/teeth.

Conclusion: Dental implant therapy is a rehabilitative treatment option that provides remarkable improvement in patients' psychosocial wellbeing and the overall patient satisfaction with the treatment is high.
\end{abstract}

Keywords: Psychosocial well-being, Self-reported satisfaction, Single implant therapy, Lagos.

\section{Introduction}

The teeth play an important role in the maintenance of a positive self-image. ${ }^{1}$ Individuals seek dental treatment for different reasons which include toothache, mouth sores, intra-oral/extra-oral swelling, presence of tooth deposits, fractured teeth, dental caries, missing teeth for replacement, routine dental check-up and halitosis. ${ }^{2}$ One of the most common reasons for dental visitation is the missing teeth replacement. This is because tooth loss may result in significant psychological, social and functional disabilities. ${ }^{3}$ To illustrate this, tooth loss gradually affects the shape of the face as well as facial contour and patients on realizing this, become anxious and stressed. All of which may ultimately result in depression. ${ }^{3}$

The various treatment options available for rehabilitating these patients in the dental clinic include removable dentures which may be complete or partial and fixed prosthesis which may be in the form of a conventional or resin-bonded bridge or an implant supported prosthesis. ${ }^{4}$ Using osseo-integrated dental implants to rehabilitate individuals with missing teeth is currently the most popular and reliable treatment option available to dental practitioners. ${ }^{5}$ It has become an appropriate and integral part of general and specialty dental practice with well documented long-term predictability that has promoted its clinical use worldwide. ${ }^{6,7}$

In recent years there have been several attempts to assess the psychological and social consequences of osseo-integrated implants, particularly those stemming from the Brånemark system. These studies have ranged from the generally anecdotal and uncontrolled evidence originally supplied by Blomberg and Linquist ${ }^{8}$ to prospective studies such as those provided by Kiyak et $\mathrm{al},{ }^{9}$ who used validated and reliable questionnaires to assess changes in well-being. There is considerable agreement that subjects that receive an implant show improvements in psychological well-being and social functioning. ${ }^{10}$ It was noted that some of these improvements could however be the result of spontaneous changes. In an attempt to control for such chance improvements, Kent and John ${ }^{11}$ followed up patients who received an implant and patients who were unable to receive the prosthesis because of anatomic difficulties. They reported that there was a significant improvement in the psychosocial well-being of subjects that were rehabilitated using dental implants, whereas the comparison group showed declining psychosocial functions.

Although there are existing reports on the treatment outcome and psychosocial effects of dental implants, ${ }^{10-13}$ 
this study aims at reporting these effects in a Nigerian and African environment.

\section{Materials and Methods}

This is a descriptive, longitudinal and interventional clinical study of patients treated with osseo-integrated dental implants. Subjects were recruited using convenience sampling method. Subjects were recruited from a Teaching Hospital as well as two private Dental Institutions in Lagos, Nigeria. Subjects were added to the study provided they met certain inclusion criteria. These criteria include individuals between 18-60 years of age, short edentulous span with not more than a tooth missing, absence of contraindications to surgical and prosthetic procedures as well as patients who gave their informed consent. Subjects with poor oral hygiene, smokers, poorly motivated or had a history of parafunctional habits were however excluded from the study. Osseo-integrated dental implants were placed by a trained implantologist who utilized the two-stage loading protocol in all cases. A self administered questionnaire with sections on biodata, experience with function, self esteem and aesthetics was used to collect data from patients. The questionnaire was administered to the subjects at two phases of the treatment. Baseline data was collected while subjects were on the waiting list before implant placement (phase T0) while post-treatment data were collected 6 months (T6) following placement. Data derived from the study was analyzed using Statistical Package for the Social Sciences (SPSS) for windows version 20. The use of tables and charts were employed for data presentation of the parameters of psychosocial wellbeing obtained at phase $\mathrm{T} 0$ and phase T6. The chisquare test was used to compare differences between discrete variables. For all comparism, $\mathrm{p}<0.05$ was inferred as the criterion for establishing a statistical significance.

\section{Results}

A total of 42 subjects were included in this study comprising of 21 males $(50.0 \%)$ and 21 females
(50.0\%). Most subjects $(\mathrm{n}=23,54.8 \%)$ were with ages 20-39 years (Table 1). Regarding the duration of edentulousness, most subjects $(n=26,65.0 \%)$ were partially edentulous for a duration between a year and 5 years while $17.5 \% \quad(n=7)$ of respondents had been partially edentulous for more than 5years. Most of the subjects $(\mathrm{n}=36,85.7 \%)$ had teeth that were missing due to extraction of either a carious teeth or severe periodontal disease while some of teeth were removed by the subjects $(\mathrm{n}=4,9.5 \%)$ or by a traditional healer $(n=2,4.8 \%)$. It was however very difficult for most subjects $(n=35,83.3)$ to initially come to terms with their edentulousness. Also, 80.9\% $(n=34)$ of subjects felt sad on losing their tooth/teeth while $16.7 \%$ felt relieved that the source of their pain or trauma has been removed.

At phase $\mathrm{T} 0,45.2 \%$ of the subjects $(\mathrm{n}=19)$ had expected that they would be comfortable with the prosthesis following the procedure while $21.4 \%(n=9)$ and $16.7 \% \quad(n=6)$ of the subjects hoped to have improved aesthetics and confidence following the treatment. Furthermore, $47.6 \%(\mathrm{n}=20)$ expected the implants to have a lifespan between $10-20$ years while $42.9 \%(n=18)$ expected it to last indefinitely (Table 2$)$.

A total of 42 implants were placed, $69.0 \%(n=29)$ were placed in various location within the mandible while $31.0 \%(\mathrm{n}=13)$ were placed in the maxilla. At phase T6, most subjects $(\mathrm{n}=41,97.6 \%)$ had an overall positive reaction to the treatment with $73.8 \%(\mathrm{n}=31)$ attesting an improvement in their facial appearance. Moreover, an improvement in self-confidence was observed in $78.6 \% \quad(n=33)$ of subjects. Regarding subjects' satisfaction with dental implant therapy, $76.2 \%(n=32)$ of the subjects were very satisfied with the outcome of the implants, $19.1 \% \quad(n=8)$ were satisfied while $2.4 \%(n=1)$ were fairly satisfied (Fig. 1). All respondents $(n=42,100 \%)$ were however willing to recommend osseo-integrated dental implants for others as the best option for tooth replacement. There was no statistically significant association ( $p>0.05)$ between the socio-demographic variables and subjects' overall satisfaction with dental implant therapy.

Table 1: Sociodemographic information of respondents

\begin{tabular}{|l|c|c|}
\hline & Frequency & Percentage (\%) \\
\hline Age (In years) & & \\
$20-29$ & 11 & 26.2 \\
$30-39$ & 12 & 28.6 \\
$40-49$ & 9 & 21.4 \\
$50-59$ & 7 & 16.7 \\
$60-69$ & 3 & 7.1 \\
Total & 42 & 100.0 \\
\hline Sex & 21 & 50.0 \\
Male & 21 & 50.0 \\
Female & 42 & 100.0 \\
Total & & \\
\hline Religion & 35 & 83.3 \\
Christianity & \multicolumn{2}{|}{} \\
\hline
\end{tabular}




\begin{tabular}{|l|c|c|}
\hline Islam & 7 & 16.7 \\
Others & 0 & 0.0 \\
Total & 42 & 100.0 \\
\hline Occupation & 5 & \\
Self Employed & 4 & 11.9 \\
Artisans & 15 & 9.5 \\
Professional Workers & 4 & 35.7 \\
Unemployed & 10 & 9.5 \\
Others & 42 & 23.8 \\
Total & & 100.0 \\
\hline Marital Status & 24 & \\
Married & 18 & 57.1 \\
Single & 42 & 42.9 \\
Total & & 100.0 \\
\hline
\end{tabular}

Table 2: Pretreatment assessment of psychosocial wellbeing of respondents

\begin{tabular}{|l|c|c|}
\hline & Frequency & Percentage (\%) \\
\hline How long ago did you lose your teeth? & 7 & \\
<12 months & 26 & 16.6 \\
1year - 5 years & 9 & 61.9 \\
>5 years & 42 & 21.4 \\
Total & & 100.0 \\
\hline How did you lose your teeth? & 36 & 85.7 \\
Extracted by a doctor & 4 & 9.5 \\
Removed by individual & 0 & 0.0 \\
Accidental removal & 2 & 4.8 \\
Self-Exfoliation & 0 & 0.0 \\
Removed by a traditional healer & 42 & 100.0 \\
Total & & \\
\hline Number of missing teeth & 25 & 59.5 \\
1 & 8 & 19.1 \\
2 & 4 & 9.5 \\
3 & 3 & 7.1 \\
4 & 2 & 4.8 \\
5 & 42 & 100.0 \\
Total & & \\
\hline Initial acceptance of tooth loss & 35 & 83.3 \\
Difficult & 7 & 16.7 \\
Easy & 42 & 100.0 \\
\hline Total & & \\
\hline Duration of acceptance of tooth loss & 29 & 69.1 \\
<6 months & 13 & 30.9 \\
>6 months & 42 & 100.0 \\
Total & & \\
\hline Feeling associated with tooth loss & 34 & 80.9 \\
Sadness & 7 & 16.7 \\
Relief & 1 & 2.4 \\
Ageing & 42 & 100.0 \\
Total & 32 & 78.5 \\
\hline Effect of tooth loss on self confidence & 8 & 100.0 \\
Affected & 32 & 76.2 \\
Unaffected & 10 & 23.8 \\
Total & 42 & 100.0 \\
\hline Effect of tooth loss on daily activities & & 19.1 \\
Restriction of activities & & 19.1 \\
No restriction of activities & & \\
Total & & \\
\hline Type of activity restricted (n $=42)$ & & \\
Choice of food & & \\
Going out in public & & \\
\hline
\end{tabular}




\begin{tabular}{|c|c|c|}
\hline $\begin{array}{l}\text { Eating in public } \\
\text { Enjoying food } \\
\text { Laughing in public } \\
\text { Creating close relationships } \\
\text { Others }\end{array}$ & $\begin{array}{c}3 \\
8 \\
23 \\
4 \\
3\end{array}$ & $\begin{array}{c}7.1 \\
19.1 \\
54.8 \\
9.5 \\
7.1\end{array}$ \\
\hline $\begin{array}{l}\text { Effect on overall facial appearance } \\
\text { Negative effect } \\
\text { No effect } \\
\text { Total }\end{array}$ & $\begin{array}{l}11 \\
31 \\
42\end{array}$ & $\begin{array}{c}26.2 \\
73.8 \\
100.0\end{array}$ \\
\hline $\begin{array}{l}\text { Confidant for discussion of tooth loss } \\
\text { Spouse } \\
\text { Family members } \\
\text { Friends } \\
\text { Dentist } \\
\text { Total } \\
\end{array}$ & $\begin{array}{r}6 \\
6 \\
3 \\
27 \\
42 \\
\end{array}$ & $\begin{array}{c}14.3 \\
14.3 \\
7.1 \\
64.3 \\
100.0\end{array}$ \\
\hline $\begin{array}{l}\text { Previous tooth replacements } \\
\text { Yes } \\
\text { No } \\
\text { Total }\end{array}$ & $\begin{array}{l}20 \\
22 \\
42\end{array}$ & $\begin{array}{c}47.6 \\
52.4 \\
100.0\end{array}$ \\
\hline $\begin{array}{l}\text { Type of previous tooth replacement (if applicable) } \\
\text { Acrylic dentures } \\
\text { Implant } \\
\text { Metallic dentures } \\
\text { Bridges } \\
\text { Others } \\
\text { Total }\end{array}$ & $\begin{array}{c}19 \\
0 \\
0 \\
1 \\
0 \\
20\end{array}$ & $\begin{array}{c}95.0 \\
0.0 \\
0.0 \\
5.0 \\
0.0 \\
100.0\end{array}$ \\
\hline $\begin{array}{l}\text { Duration of use of tooth prosthesis (if applicable) } \\
1-3 \text { years } \\
4-5 \text { years } \\
6-10 \text { years } \\
>10 \text { years } \\
\text { Total }\end{array}$ & $\begin{array}{c}10 \\
5 \\
2 \\
3 \\
20\end{array}$ & $\begin{array}{r}50.0 \\
25.0 \\
10.0 \\
15.0 \\
100.0\end{array}$ \\
\hline $\begin{array}{l}\text { Current use of tooth prosthesis } \\
\text { Yes } \\
\text { No } \\
\text { Total }\end{array}$ & $\begin{array}{c}15 \\
5 \\
20\end{array}$ & $\begin{array}{c}75.0 \\
25.0 \\
100.0\end{array}$ \\
\hline $\begin{array}{l}\text { Reason for not currently using the tooth prosthesis (if } \\
\text { applicable) } \\
\text { Got lost } \\
\text { Unsatisfied with the prosthesis } \\
\text { Total }\end{array}$ & $\begin{array}{l}2 \\
3 \\
5\end{array}$ & $\begin{array}{c}40.0 \\
60.0 \\
100.0\end{array}$ \\
\hline $\begin{array}{l}\text { How did you know about dental implants? } \\
\text { Dentist } \\
\text { Friend } \\
\text { Media } \\
\text { Total }\end{array}$ & $\begin{array}{c}34 \\
8 \\
0 \\
42\end{array}$ & $\begin{array}{c}81.0 \\
19.0 \\
0.0 \\
100.0\end{array}$ \\
\hline $\begin{array}{l}\text { Expectations to be satisfied by the implants } \\
\text { Enhance communication } \\
\text { Improve Confidence } \\
\text { Comfort } \\
\text { Improve mastication } \\
\text { Improve aesthetics } \\
\text { Total }\end{array}$ & $\begin{array}{c}1 \\
7 \\
19 \\
6 \\
9 \\
42\end{array}$ & $\begin{array}{c}2.4 \\
16.7 \\
45.2 \\
14.3 \\
21.4 \\
100.0\end{array}$ \\
\hline $\begin{array}{l}\text { Expected duration of implants by subjects } \\
5-10 \text { years } \\
10-20 \text { years } \\
\text { Indefinitely } \\
\text { Total }\end{array}$ & $\begin{array}{c}4 \\
20 \\
18 \\
42\end{array}$ & $\begin{array}{c}9.5 \\
47.6 \\
42.9 \\
100.0\end{array}$ \\
\hline
\end{tabular}


Table 3: Assessment of psychosocial wellbeing of patients six (6) months post treatment

\begin{tabular}{|c|c|c|}
\hline 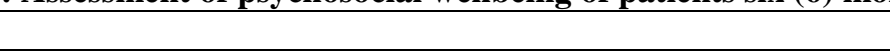 & Frequency & Percentage \\
\hline $\begin{array}{l}\text { Tooth/Teeth replaced with dental implant(s) } \\
\text { Incisor } \\
\text { Canine } \\
\text { Premolar } \\
\text { Molar } \\
\text { Total }\end{array}$ & $\begin{array}{c}26 \\
1 \\
7 \\
8 \\
42\end{array}$ & $\begin{array}{c}61.8 \\
2.4 \\
16.7 \\
19.1 \\
100.0\end{array}$ \\
\hline $\begin{array}{l}\text { Site } \\
\text { Maxilla } \\
\text { Mandible } \\
\text { Total }\end{array}$ & $\begin{array}{l}13 \\
29 \\
42\end{array}$ & $\begin{array}{c}31.0 \\
69.0 \\
100.0\end{array}$ \\
\hline $\begin{array}{l}\text { Reaction following placement of implant } \\
\text { Positive } \\
\text { Negative } \\
\text { Total }\end{array}$ & $\begin{array}{c}41 \\
1 \\
40\end{array}$ & $\begin{array}{c}97.6 \\
2.4 \\
100.0\end{array}$ \\
\hline $\begin{array}{l}\text { Current preferred option for tooth replacement } \\
\text { Dental implant } \\
\text { Removable denture } \\
\text { Bridges } \\
\text { Total }\end{array}$ & $\begin{array}{c}42 \\
0 \\
0 \\
42\end{array}$ & $\begin{array}{c}100.0 \\
0.0 \\
0.0 \\
100.0\end{array}$ \\
\hline $\begin{array}{l}\text { Effect on self confidence } \\
\text { Positive effect } \\
\text { Never lost self-confidence } \\
\text { Total }\end{array}$ & $\begin{array}{c}39 \\
3 \\
42\end{array}$ & $\begin{array}{c}92.8 \\
7.2 \\
100.0\end{array}$ \\
\hline $\begin{array}{l}\text { Overall improvement in facial appearance } \\
\text { Yes } \\
\text { No } \\
\text { Total }\end{array}$ & $\begin{array}{c}36 \\
6 \\
42\end{array}$ & $\begin{array}{c}85.7 \\
14.3 \\
100.0\end{array}$ \\
\hline $\begin{array}{l}\text { What restricted activity are you able to perform now? } \\
\text { Going out in public } \\
\text { Outdoor eating } \\
\text { Better mastication } \\
\text { Laughing in public } \\
\text { Creating close relationships } \\
\text { Better speech }\end{array}$ & $\begin{array}{l}9 \\
10 \\
40 \\
28 \\
10 \\
42\end{array}$ & $\begin{array}{l}21.4 \\
23.8 \\
95.2 \\
66.7 \\
23.8 \\
100.0\end{array}$ \\
\hline $\begin{array}{l}\text { Presence of symptom since implant placement } \\
\text { Yes } \\
\text { No } \\
\text { Total }\end{array}$ & $\begin{array}{c}3 \\
39 \\
42\end{array}$ & $\begin{array}{c}7.1 \\
92.9 \\
100.0\end{array}$ \\
\hline $\begin{array}{l}\text { Symptom experienced (if applicable) } \\
\text { Pain } \\
\text { Mobile tooth } \\
\text { Total }\end{array}$ & $\begin{array}{l}1 \\
2 \\
3\end{array}$ & $\begin{array}{c}33.3 \\
66.7 \\
100.0\end{array}$ \\
\hline $\begin{array}{l}\text { Satisfaction with colour shade of dental improvement } \\
\text { Yes } \\
\text { No } \\
\text { Total }\end{array}$ & $\begin{array}{c}41 \\
1 \\
42\end{array}$ & $\begin{array}{c}97.6 \\
2.4 \\
100.0\end{array}$ \\
\hline $\begin{array}{l}\text { Which would you prefer if you need to replace another tooth? } \\
\text { Dental implant } \\
\text { Total }\end{array}$ & $\begin{array}{l}42 \\
42\end{array}$ & $\begin{array}{l}100.0 \\
100.0\end{array}$ \\
\hline $\begin{array}{l}\text { Will you recommend implant replacement for others? } \\
\text { Yes } \\
\text { Total }\end{array}$ & $\begin{array}{l}42 \\
42\end{array}$ & $\begin{array}{l}100.0 \\
100.0\end{array}$ \\
\hline
\end{tabular}




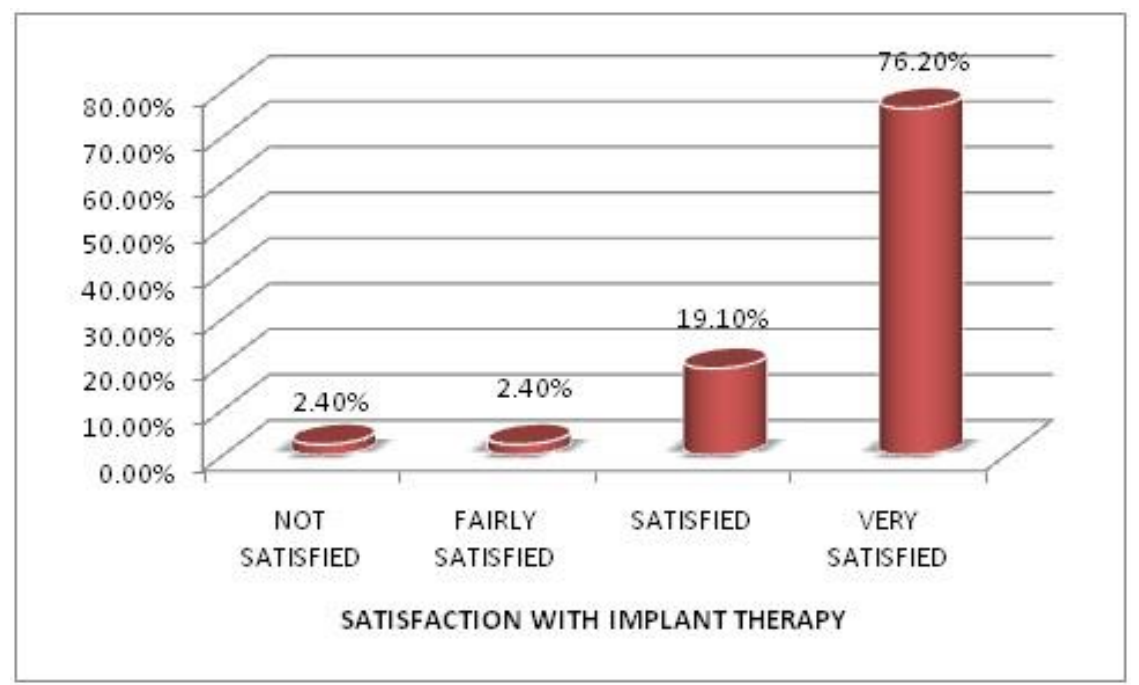

Fig. 1

\section{Discussion}

This descriptive, longitudinal study investigated the effect of osseo-integrated dental implants on psychological and social wellbeing of a total of 42 respondents. The respondents have an equal sex distribution as there were 21 males $(50.0 \%)$ and 21 females $(50.0 \%)$. This is in contrast with the reports of Ogbebor et $\mathrm{al}^{2}$ that females tend to seek dental treatments generally more than males. The reason for this may be due to the increasing number of male subjects wanting a more permanent replacement for missing teeth for aesthetic and comfort reasons.

The overall satisfaction of subjects with single implant therapy in this study is $76.2 \%$. This is however lower but similar to the reports of other studies. ${ }^{14-16}$ Levi et al ${ }^{14}$ reported an overall satisfaction rate of $88 \%$ in a study involving 76 subjects that had placement of anterior maxillary implants. This is also consistent with the reports of Avivi-Arber ${ }^{15}$ and Carlson et al ${ }^{16}$ with overall self-reported satisfaction rates of $88 \%$ and $83 \%$ respectively.

In this study, there was no significant association between overall satisfaction and the sociodemographic factors which was also consistent with the observations of Chang et $\mathrm{al}^{17}$ and in contrast with the reports of Vallittu et $\mathrm{al}^{18}$ and Klima et al. ${ }^{19}$ In addition, most subjects were also satisfied with the colour shade of their implant restoration which is similar with what was obtained by Levi et al. ${ }^{14}$ All the subjects in this study $(100.0 \%)$ indicated that they would be willing to redo the same treatment if future need arises as well as recommend implant therapy to others. This report is higher than what was obtained by Levi et al where $67.0 \%$ of the subjects were willing to do the treatment for other teeth that might be needing replacement in the future while $68.0 \%$ were willing to recommend it to a friend.

Regarding the psychosocial wellbeing of the subjects, at phase T0 most subjects (78.5\%) lacked self confidence while tooth loss did not affect the self confidence of $21.5 \%$ of subjects. Following dental implant therapy (phase T6), $92.8 \%$ of the subjects had improved self confidence while $7.2 \%$ of them believed that the treatment did not in any way improve their self confidence. Also, at phase T6, $85.7 \%$ of subjects agreed that there was an improvement in their facial appearance following the treatment. The improved psychosocial wellbeing observed in this study agrees with the reports of Rashika et $\mathrm{al}^{20}$ that demonstrated an improvement in the psychosocial impacts of subjects following implant therapy.

\section{Conclusion}

Dental implant therapy is currently regarded as the gold-standard for rehabilitating edentulous patients. This study observed that it considerably improves the psychosocial wellbeing of individuals over a period of six (6) months. Also patients' satisfaction following single implant therapy is high. Hence, whenever applicable, dental implant therapy should be strongly considered for rehabilitating partially edentulous patients in Nigeria and Sub-Saharan Africa. The authors however affirm that there is a need to recruit more subjects and continue subjects' follow-up so as to evaluate the psychosocial wellbeing and satisfaction of patients to dental implant therapy over a longer period of time.

\section{References}

1. Roessler DM. Complete denture success for patients and dentists. Int Dent J. 2003;53:340-5.

2. Ogbebor OG, Azodo CC. Reasons for seeking dental healthcare services in a Nigerian missionary hospital. Sahel Med J. 2016;19:38-43.

3. Fiske J, Davis DM, Frances C, Gelbier S. The emotional effects of tooth loss in edentulous people. Br Dent J. 1998;184:90-3.

4. Al-Quaran FA, Al-Ghalayini RF, Al-Zu'bi BN. Single tooth replacement: Factors affecting different prosthetic treatment modalities. BMC Oral Health. 2011;11:34-38. 
5. Teresa Duncan. Grin and bear It: Dental implants are the best option for replacing teeth. Insight into the world of Dentistry - Implant and Otherwise. March, 2012

6. Klokkevold PR. Implant education in the dental curriculum. J Calif Dent Assoc. 2001;29:747-755

7. Mayer TM, Hawley CE, Gunsolley JC. The single-tooth implant: A viable alternative to single-tooth replacement. J Periodontol. 2002;73:687-693.

8. Blomberg S, Linquist LW. Psychological reactions to edentulousness and treatment with jawbone-anchored bridges. Acta Psychiatr Scand. 1983;68:251-262.

9. Kiyak HA, Beach B, Worthington P, Taylor T, Bolender $\mathrm{C}$, Evans J. The psychological impact of osseointegrated dental implants. Int J Oral Maxillofac Implants. 1990;5:61-69.

10. Kent GG. Effects of osseointegrated implants on psychological and social well-being: A literature review. J Prosthet Dent. 1992;68:515-518.

11. Kent GG, Johns R. A controlled longitudinal study on the psychological effects of osseointegrated dental implants. Int J Oral Maxillofac Implants. 1991;6:470-474.

12. Boerrigter EM, Geertman ME, Van Oort RP, Bouma J, Raghoebar GM, van Waas, MA. Patient satisfaction with implant-retained mandibular overdentures. A comparison with new complete dentures not retained by implants $-\mathrm{a}$ multicentre randomized clinical trial. British Journal of Oral \& Maxillofacial Surgery. 1995;33:82-288

13. Batenburg RHK, Meijer HJA, Raghoebar GM, van Oort RP, Boering, G. Mandibular overdentures supported by two Brånemark, IMZ or ITI Bonefit implants. A prospective comparative study. One year results. Clinical Oral Implants Research. 1998;9:374-383.

14. Levi, Anna, "Patient Self-Reported Satisfaction with Maxillary Anterior Dental Implant Treatment." (2001). SoDM Masters Theses. http://digitalcommons.uconn.edu/sodm_masters/78

15. Avivi-Arber L, Zarb GA. Clinical effectiveness of implant-supported single tooth replacement: The Toronto study. Im J-Oral Maxillofac Implants 1996; 11:311-321

16. Carlson B, Carlsson GE. Prosthodontic complications in osseointegrated dental implant treatment. Int J Oral Maxillofac Impl. 1994;9:90-94.

17. Chang M, dman PA, Wennstrom JL, Bernt A. Esthetic outcome of implant supported single tooth replacements assessed by the patient and by prosthodontists. Int $J$ Prosthodont. 1999;12:335-341.

18. Vallittu PK, Vallittu ASJ, Lassila VP. Demal aesthetics- a survey of attitudes in different groups of patients. J Dent. 1996;(24):335-338.

19. Klima RJ, Wittermann JK, McIver JE. Body image, selfconcept and the orthodontic patient. Am J Ortho. 1979;75(5):507-16.

20. Rashika V. Psychological Impacts of Implant patients. Int $J$ of Recent Advances in Multidisciplinary Res. 2015;2(7);540-542. 